Article

\title{
The End of Television-Again! How TV Is Still Influenced by Cultural Factors in the Age of Digital Intermediaries
}

\author{
Gunn Enli * and Trine Syvertsen \\ Department of Media and Communication, University of Oslo, 0317 Oslo, Norway; E-Mails: gunn.enli@media.uio.no \\ (G.E.), trine.syvertsen@media.uio.no (T.S.) \\ * Corresponding author
}

Submitted: 31 December 2015 | Accepted: 25 February 2016 | Published: 14 July 2016

\begin{abstract}
This article discusses the impact of convergence and digital intermediaries for television as a medium, industry and political and cultural institution. There is currently widespread debate about the future of television and the impact of technological and market changes. Our argument is that the answer to what is happening to television cannot be adequately addressed on a general level; local and contextual factors are still important, and so is the position and strategic response of existing television institutions in each national context. Based on analyses of political documents, statistics, audience research and media coverage, as well as secondary literature, the article explores the current situation for Norwegian television and point to four contexts that each plays a part in constraining and enabling existing television operators: the European context, the public service context, the welfare state context and the media ecosystem context.
\end{abstract}

\section{Keywords}

convergence; Norway; public service broadcasting; television

\section{Issue}

This article is part of the issue "(Not Yet) the End of Television", edited by Milly Buonanno (University of Roma "La Sapienza", Italy).

(C) 2016 by the author(s); licensee Cogitatio (Lisbon, Portugal). This article is licensed under a Creative Commons Attribution 4.0 International License (CC BY).

\section{Introduction}

There is currently widespread debate about what is happening with television and how technological and market changes may undermine the medium's future. ${ }^{1}$ The article argues that the answer to what is happening to television cannot be adequately answered on a general level-television's future is not just determined by technological and economic developments, but also by local and contextual factors: history, structure, regulation, user patterns, as well as the position and strategic response of specific institutions in each national context. The article draws on political documents, statistics, audience research, and media coverage, as well as previ-

${ }^{1}$ For an overview over how the forces challenging traditional television are discussed on the level of policy, see, for example, (DAF/COMP/GF (2013)13). ous studies and secondary literature, to discuss factors influencing the future of television and relate these to a specific national case. With few exceptions (see, for example, Dhoest \& Simons, 2013; Turner \& Tay, 2009) the debate about the future of television builds on evidence from large countries, predominantly from the AngloAmerican sphere. The article contributes by focusing on a Nordic country, characterized by a combination of a high usage of global online streaming services, but also high use of public service television and high demand for domestic content. As Pertierra and Turner (2013) argue, television studies can only move forward if the object of study is more explicitly located within specific political economic and geo-linguistic spaces.

Theoretically, the article draws on perspectives on economic and technological change, as well as theories of "media welfare state" and "media ecosystems" pointing to cultural and political factors. The analysis is 
divided into three parts, each with an accompanying research question. These are: 1 ) What are the current changes in contemporary technologies, contents, markets and industries that point towards a fundamental change in the understanding of and conditions for television? 2) Which political, economic and cultural contexts may help to explain differences between national cases in how television develops, which contexts are particularly relevant in the Norwegian case, and how do these contexts enable or constrain existing TV companies? 3) How do traditional television institutions in Norwaypublic service as well as private-respond to the general and specific challenges and with what impact? The discussion is framed by a general introduction on "the end of television" debate and ends with a concluding discussion on the factors shaping television today.

\section{2. "The End of Television"-Again!}

The changing conditions for television are a hot topic, both in the trade press and in academic conferences and papers. Titles like Traditional TV has survived the net threat, but for how much longer? (Naughton, 2012), Online streaming services are becoming a threat to broadcast television (Morrison, 2014), and Cordnevers could be bigger threat to TV than cord-cutters (Harris, 2015), indicate a new turnaround in the spiral of change that for decades have dominated industry and journalistic discourse on television. Changes in technologies and markets, as well as the emergence of new services with new business models, are not only seen to threaten the position of established market actors, but the very understanding and definition of television. Indeed, in academic contributions the very term "television" seems to need an increasing number of add-ons to be precise. Since the turn of the century, research literature has suggested to separate between definitions such as "broadcast TV" and "post-broadcast TV", "TV" and "television", "linear-TV" and "non-linear TV" (Lotz, 2007; Olsson \& Spiegel, 2004; Turner \& Tay, 2009).

Despite attempts at clarification, it is not always easy to understand which aspects of television that are challenged or threatened by which forces. The most common understanding of (traditional) television is that it is a system of distributing mixed schedule programming simultaneously to a mass audience watching in their homes on traditional sets, and where advertising and fees are the most important sources of revenue (Doyle, 2015; Ellis, 2000; Katz \& Scannell, 2009). This model seems to be challenged on at least three counts. First, the fragmentation of audiences may undermine the mass media aspect of television; second, traditional television companies may not be able to acquire the content they need to uphold an attractive schedule, and third, the very business model may be undermined as both viewers and advertisers are seen as migrating away from the broadcast platform.
The challenges are real and important and have considerable impact on both the understanding of and conditions for television. Yet, we agree with those who are sceptical of the current tendency to talk in terms of boom and doom-boom for new media and doom for television (Donders, Pauwels, \& Loisen, 2013, pp 1120). The rhetoric in the debates is infused by expectations of immense progress or of steep decline, and the predictions about revolution in the TV sector are often voiced by actors who have vested interests in the realization of these predictions. An illustrative example is that the co-founder and chief executive officer (CEO) of the online TV streaming company Netflix, Reed Hastings, in 2015 argued that "In ten years-time, or twenty at the most, linear TV with a fixed schedule will be dead". He points to how the landline telephone became irrelevant with the introduction of the cell phone, and predicts that online streaming will similarly replace traditional TV. This type of rhetoric gets broad coverage; the press covers new actors such as Netflix and new trends in TV usage such as "binge watching" extensively, but are less fascinated with stories about the resilience of traditional forms of television. A key rhetorical challenge for traditional TV companies is to combat the image of an old-fashioned, irrelevant, and dying industry, which is partly constructed by their new competitors' marketing strategists.

In the light of the dire predictions for traditional television, two points are particularly important. The first point is historical: We are not the first generation to be faced with the question of "what is television?" (or what is any other medium for that matter). Television was not defined from the start, and the introduction of the new medium caused a series of debates about how to characterize TV, most often based on definitions of existing media technologies (Enli, 2015 p. 48). Since these early days, television has gone through many phases and taken on various forms such as experimental, monopoly, paternalist public service, competition, scheduling, niche channels, cable and satellite, on-demand and pay-tv-each with separate features that impact on how television is understood.

In the last three decades, debates about television have increasingly been framed in a context of radical change. From the 1990s onwards, cyber-optimists such as George Gilder have celebrated the coming of internet as liberation from the "tyranny" of television (Life after television, 1992). The predictions and debates continued throughout the late 1990s and 2000s with debates and book titles such as The end of television? (e.g. Katz \& Scannell, 2009). While all this went on, however, there was massive reorientation and strategic decision-making in television companies, including the decision to digitalise production and distribution and develop niche channels and online services. After a quarter of a century of "the end of television", it is interesting that there is still so much television left to debate. 
The other initial point is political: Different stakeholders have different stakes in defining television; definitions are not apolitical but serve specific purposes. A lot of the current confusion around how to define television is rooted in regulatory challenges; for regulators it is important to decide whether or not something is television because this determines how it should be regulated. The regulatory definitions need to be very precise, because imposing a wrong framework may be perilous to innovation, unfair to certain operators and damage the reputation of the regulators. As a rule, traditional broadcasters are regulated stricter than paytelevision whereas online services have the least strict regulatory framework. ${ }^{2}$ Faced with new types of audiovisual content, regulators struggle with categorization, and decisions are contested. Girginova (2015) discuss some interesting examples where the British regulator OFCOM has determined that certain clips are "TV-like", based on technical and economic dimensions; cultural and contextual dimensions, and the degree to which the purpose of the services are comparable with TV (Girginova, 2015). Operators often disagree, however, and in the case of a particular on-line service, "Top Gear YouTube", the BBC protested, claiming that clips were not intended to be consumed like TV, but as "tasters" of the television shows (Ofcom, 2013).

This demonstrates that the understanding of what TV is has not only changed historically, but fluctuates according to perspective and stakeholder interest. The definition of television cannot be reduced to technical specificities as television is infused with history and cultural meaning. While it is easy to describe a linear model of television using technological and economic characteristics, what we may call "cultural models of television" display varying features from context to context.

From the medium's early history, many have analysed television as culture, cf. seminal analyses such as Raymond Williams' Television-technology and cultural form (1974/2008). As Lotz (2014) points out, "[f]oundational understandings of television view it as a-if not the-central communicative and cultural force in society." This position derives from television's "availability and ubiquity" (emphasis in original) and its role as a conveyor of information that "reflects, challenges and respond to shared debates and concerns" (p. 37). In addition, Lotz discusses television as a cultural industry, which in the US implies that it "operates as a commercial enterprise that primarily seeks to maximise profits, while nonetheless producing programs that are important creative and cultural forms that communicate social values and beliefs" (p. 37). In this article, we are concerned with television both as a transmitter of culture and as a cultural industry, in this case as an industry with somewhat different characteristics than US television. However, we are also con-

${ }^{2}$ See for example Levy (1999). cerned with television as culture in a wider sense; television as a product of, and a constitutive element in, certain national and regional political cultures. We discuss how different cultural and political contexts impose general and specific expectations of what television should do that goes beyond television as a cultural industry or medium of storytelling.

In the article we join forces with scholars who point to the importance of continuity when studying the development of television (Dhoest \& Simons, 2013; Ellis, 2000; Gripsrud, 2010; Tay \& Turner, 2010). ${ }^{3}$ Perriera and Turner (2013) use the concept of "zones" to describe "the various contexts and scales in which television can be located" (p. 6); zones include households, communities and nations, as well as a more discursive zone of "modernity". By locating television in various zones, Pertierra and Turner identify disruptive as well as stabilising forces and point to several forms of resilience that is underestimated in the current debates, such as the "resilience of the state as an actor in the media sector" (p. 47), "the resilience and persistence of the national even within highly commercialized media environments" (p. 52) and "what some see as a surprising resilience in the free-to-air audience" (p. 9). Accordingly, Pertierra and Turner (2013) argue that research should increasingly focus on the impact of cultural factors on TV's development, and suggests that studies should draw on evidence from different contexts to counter the tendency to see developments as "linear, evolutionary process with only a single point of destination" (p. 11).

The authors of this article have previously analysed transitions in television (Enli, 2008, 2015; Enli, Moe, Sundet, \& Syvertsen, 2013; Ihlebæk, Syvertsen, \& Ytreberg, 2013; Syvertsen, 1992, 1997, 2008). We observe that each transition to some degree recycles established patterns, yet, in each transition there are also new elements creating a particular kind of confusion and disruption. Consequently, we are concerned about both continuity and change, and both about general forces and the geographical and cultural specificities in a national setting.

\section{Convergence and Digital Intermediaries}

We turn now to the first of our analytical research questions 1) What are the current changes in contemporary technologies, contents, markets and industries that point towards a fundamental change in the understanding of and conditions for television? The specific impact of convergence for existing media is complex to disentangle and subject to much discussion and debate

\footnotetext{
${ }^{3}$ As Dhoest and Simons (2013, p. 19) argue, the current changes are real and important, yet, "[i]ndustry and journalistic discourses in particular seem to be so preoccupied with changes and innovations that mainstream contemporary television practices all but disappear from view".
} 
(Dwyer, 2010; Jenkins, 2006; Jensen, 2010; Lotz, 2014; Staiger \& Hake, 2009). In this article, the discussion is narrowed down to the challenges which are currently causing most tensions: the disruptive impact of socalled digital intermediaries.

Digital intermediaries, also called "internet intermediaries" or "digital disruptive intermediaries (DDI)", are often understood as a third party which enters an industry and provides new digital services that challenge established business models and change the way value is created or distributed (Riemer, Gal, Hamann, Gilchriest, \& Teixeira, 2015). The term digital intermediaries refers to a mixed group of services that have in common that they function as algorithm-based gatekeepers; among the prominent sub-categories are news aggregators, social media, search engines, digital stores and content providers (Mansell, 2015). The most disruptive digital intermediaries in regards to linear television are content aggregators such as Netflix, HBO, Amazon and YouTube, in addition to the digital media player and micro console AppleTV, which represents a significant gatekeeper to and third party provider of TV content.

The impact of digital intermediaries varies between the services and there are also differences in production, distribution, and business models. YouTube is a hybrid media environment where both users and established companies distribute their content without costs, thus reducing the traditional distinction between professionally produced and user-generated content. Netflix, on the other hand, distributes professionally produced content to paying subscribers, and competes much more directly with established TV operators for content, audiences and revenue. Along with similar services (such as HBO and Hulu in the US), these services directly challenge the principles of linear distribution and mixed scheduling. Social media such as Facebook may be both disruptive and supportive to traditional television in a variety of ways; they provide viewers with audio-visual content, serve as add-ons to existing shows, are used for promotion (MarketingCharts, 2014) and viewer engagement, and work as a vehicle for interactive advertising.

In addition to their separate features, the digital intermediaries together accelerate the general economic and technological pressures on television. First, digital intermediaries increase audience fragmentation by making viewing more individualized; viewers are liberated from schedules and freed to make personalized choices about what programmes to watch at what times, on what devices and through which platforms. New technologies have, as Lotz (2014, p. 40) puts it "ruptured the norm of simultaneity in television experience and enabled audiences to capture television on their own terms". Consequently, TV begins to function less as a "flow" medium and more like publishing (bookstore, library) (p. 39), and it is more difficult to uphold a common sphere.
Second, digital intermediaries challenge television's position as content-provider. Internet-only channels like Netflix and Amazon Prime Instant Video do not only compete with traditional TV-firms by delivering content directly to fee-payers, they also produce original content based on more specific user data than traditional TV companies (Carr, 2013). As competition for attractive content increases, new divisions are becoming visible between different types of content that defies traditional genre divisions. Lotz (2014) distinguishes between three tentative categories based on functions for the viewers: "Prized content" which "people seek out and specifically desire" such as original and popular drama series (p. 12), "live sports and contests" which are exceptional and time sensitive ( $p$. 13), and "linear content" which is what audiences watch for companionship, distraction and entertainment (p. 15).

Third, digital intermediaries position themselves to challenge established business models through a mixture or marketing strategies, content strategies, and rhetorical strategies. The new entrants argue that streaming and online services contribute to progress and innovation, price-reduction and customer satisfaction, as well as increased quality in content. The confidence of the newcomers is partly based on the tendency of "cord-cutting" among the so-called millennials (a term referring to consumers dropping cable or satellite TV subscription in favour of online video sources) ${ }^{4}$, and the fact that younger viewers everywhere watch less linear television. Although convergence and cordcutting challenge both advertising and licence fees as business models, the threat to advertising is more profound because it is more dependent on linear-TV. Internet advertising is growing and about to close the gap to television in the market for audio-visual advertising, there is yet no viable business model for audiovisual content on platforms such as smart phones that equals the traditional thirty second ad, and television increasingly must supplement traditional sources of revenue with show-by-show-based funding such as placement, integration, branded events and sponsorship (Lotz, 2014).

The fourth factor is of a more political nature pointing beyond market and technology to the next part of our analysis; the digital intermediaries' reluctance to being defined as media companies, defining themselves instead as technology companies not subject to audio-visual regulations (Napoli, 2014). Digital intermediaries are not regulated through licences or contracts with governments and not obliged to provide certain programming or contribute to local content production. The companies still engage with policy; Netflix has for example engaged lobbyists in Washing-

4 see e.g. Strangelove (2015), and http://www.digitaltrends. com/topic/cord-cutting-101 
ton DC to promote liberalization of restrictions on personal data-sharing, as well as voicing their interests in net neutrality and bandwidth caps (Johnston, 2012) but tend to ignore invitations to consultations regarding for example contributions to domestic production. In a response to such an invitation from the Norwegian Ministry of Culture, Netflix' chief of communication Joris Evers claimed that executives were busy: "We follow the Norwegian debate with interest, but can unfortunately not be present in all forums." (Tobiassen, 2015; Vollan 2015).

These examples demonstrate the potential impact of digital intermediaries for televisions' relationship with audiences, producers, financiers and stakeholders. But television isn't just a technology with some content-or "a toaster with pictures" as former FCC Chairman Mark Fowler named it at the height of deregulation in the US. ${ }^{5}$ Television is infused with meaning, history and culture, and is deeply woven into the social fabric.

\section{Political and Cultural Contexts}

Comparative studies show that political and cultural contexts continue to be important for how television develops, and not least for the ability of existing television companies to design effective strategies in the current situation. ${ }^{6}$ We turn now to the second research question: 2) Which political, economic and cultural contexts may help to explain differences between national cases in how television develops, which contexts are particularly relevant in the Norwegian case, and how do these contexts enable or constrain existing TV companies? Four contexts will be discussed with relevance for Norwegian television: the European context, the public service media context, the welfare state context and the "media ecosystem" context.

Norway is a European country, i.e. part of a territory where television to a high degree has been ascribed social and cultural functions. In Europe, there is much concern and public debate about the challenges of new digital services. The European market is fragmented compared to the US, and one concern is about whether increased competition and new distribution models will undermine demand for European content and/or production. Just as concerns were raised about "Dallasification of TV content" in the 1970s and 1980s (Miller, 2003) the term "Googlization of everything" (Vaidhynathan, 2011) can stand as a metaphor for some of the current debates. A concern for EU policy makers is that the current digital market in Europe is made up by $54 \%$ US online services, $42 \%$ national online services, and only $4 \%$ EU cross-border online services (European

\footnotetext{
${ }^{6}$ See, for example, Ibarra, Nowak and Kuhn (2015) on public service television and Donders et al. (2013) for private television.
}

Commission, 2015a). The European political strategy, under the label of the Digital Single Market, encompasses different responses to encourage free flow of online services and entertainment across European national borders. A stated goal for EU policy makers is to safeguard media pluralism, and to guarantee the independence of national media regulators in the age of convergence. The on-going review of the EU Audiovisual Media Service Directive includes a public consultation where member states and other stakeholders expressed their opinions, European Commission (2015b) and is intended to outline new principles for deciding whether new types of services should be subject to regulation, and to reduce the uneven playing field between operators. In addition to regulatory changes, the EU is continuing the financial support for European culture and media through the Creative Europe programme such as drama, animations and documentaries (European Commission, 2016) This type of content may not just serve as "prized content" specifically desired by audiences; it is also a type of content desired by regulators, policy makers and stakeholders active in the cultural sphere. Parallel to the increased availability of US content, there is increased production of national content and Nordic and European coproduction. This counter-trend can additionally be explained by institutional strategies and international trends, such as the BBCs strategies for export, increased global format trade, and the popularity of Nordic noir (Hill \& Steemers, 2011; Weissmann, 2009). This fits well with a historical lesson: even if US products have become hugely popular in Europe, there have been continued demand for domestic services and products, and willingness to use public funding to sustain quality productions. ${ }^{7}$

The second context is the public service media context; Norway belongs to the group of countries constituting the heartland of public service broadcasting, along with Britain, Germany, the Netherlands, Belgium and Japan (McKinsey, 2004; Mendel, 2000; Moe \& Syvertsen, 2009). The public service tradition in these countries is very different from the US system of public broadcasting which is much more marginal and poorly funded (Freedman, 2008). At each point of transition, the public service broadcasting institutions have lost audiences and key content to competitors, and there are constant discussions over the viability of public funding (Born, 2003; Donders \& Pauwels, 2008; Levy, 1999). In spite of this on-going debate, however, the public service media companies have retained a stronger position than most observers expected, and have sustained popularity and legitimacy (Lowe \& Martin, 2014; Moe, 2009; Syvertsen, 2008; Syvertsen, Enli,

\footnotetext{
7 In the US only a couple of dollars per capita are spent on public media whereas spending in Northern Europe are above fifty or even hundred dollars per capita (Kenyon, 2014, p. 387)
} 
Moe, \& Mjøs, 2014). The attempts to restrict public service on the European level have not been successful (Donders, 2013), instead, much of the future of public service media continue to be determined nationally (Moe, 2007, p. 52). In the countries representing the heartland of public service broadcasting, the institutions' future continues to be one of the most salient issues in cultural debates, and a variety of stakeholders are engaged to preserve what they see as their crucial characteristics. Two issues are indicative of the type of support the institutions are enjoying: the legitimacy of the business model and the degree to which they are allowed to develop online services in new markets. On both counts the Norwegian conditions are favourable for public broadcasters: in 2015, 70\% said they were getting value for money by paying the fee (Myhre, 2015) and the conservative/right-wing government in 2015 decided to retain the licence fee for the time being (Kulturdepartementet, 2015). Legislation has also allowed the public media company to expand onto digital and online platforms in order to sustain a competitive position (Bulck \& Donders, 2014; Moe, 2009).

In addition to the European and public service context, Norway belongs to the Nordic region of welfare states. Also the implications of this context point in different directions. On the one hand, Nordic welfare states have attached great importance on media as a vehicle to change society. Syvertsen et al. (2014) labels the media policy construction in the Nordic countries "the media welfare state" and argues that national media, and in particular television, continue to be treated as important welfare state institutions: universally available, with social purposes and a stated mission to facilitate integration, democratic dialogue and national culture. Like other fundamental aspects of the welfare state, there has been political consensus surrounding central media policy aims, and broad support for the idea that the state is obliged to uphold infrastructure to facilitate "an enlightened public conversation" $^{\prime \prime}$ (see also Kulturdepartementet, 2015, p. 7). On the other hand, this also implies that there is consensus about the need for public institutions and policies to change and adapt, not least to become more innovative in terms of a digital future (Moe, 2009). Nordic welfare states are not just characterised by a high level of state regulation, they are also known for economic wealth and adaptability, and high take-up of new services such as online news, online shopping, social me-

8 This expectation is to some degree strengthened in recent decades. In 2004, the Norwegian constitutions' paragraph on free speech (para. 100) was amended obliging the state to facilitate infrastructure to secure "an enlightened public conversation" (Sønneland, n.d.), and this obligation was used in 2015 to justify the current conservative-right wing government's continuing support for publicly funded media (Kulturdepartementet, 2015). dia, and digital streaming services (Syvertsen et al., 2014). The take-up of Netflix in Norway is a telling example; since its launch in October 2012 the service grew rapidly to reach $30 \%$ of all households in 2015 making Norway a top user of the streaming service (Fossbakken, 2015). Consequently, the context of a (wealthy) Nordic media welfare state implies an interesting combination of enabling and constraining factors: both increased competition for traditional television institutions and continuing support for their cultural and political functions.

The fourth context is that of media ecosystems. The concept of media ecosystem is used in many different ways, pointing to the increasing interdependence of different media and technologies and how developments in one sector affect others (Colapinto, 2010; Hiler, 2002; Lasica, 2003). In this context, the concept of ecosystem implies a perspective where existing national television companies are not judged solely on their own merits, but seen as vehicles to regulate and obtain results across the media market. A study of private-public partnership in another small TV market, that of Flanders (part of Belgium) describe the regulatory approach to television as a strategic "ecosystem approach" in which policy-makers encourage collaboration between private and public institutions (Raats \& Pauwels, 2013)..$^{9}$ In this approach, public and private media are not seen as opposites competing with each other, but as elements in a common system, complementing each other, and the role of public service media are explicitly defined as that of a standard setter for the whole industry. Public media companies are expected to raise quality and diversity overall, as well as serving as a "digital locomotive"; spearheading the transition to information societies and lead in innovation and risk-taking (Aslama \& Syvertsen, 2007). Furthermore, public service companies are increasingly obligated to decrease their competitive stance vs other operators; instead of competing head-on with private television and new media, they should cooperate and act as facilitators. The Norwegian Government's recent white paper on public service broadcasting suggests that the Norwegian broadcasting corporation (NRK) should have "an independent responsibility for media pluralism" (Kulturdepartementet, 2015). The 'ecosystem' approach is a response to strong criticism that public media institutions have become too privileged and a threat to private actors, and is part of an effort to find new legitimation for public service media. At the same time, the approach has the potential of making existing television institutions more outward-looking as the focus is moved to the public broadcasters' sur-

\footnotetext{
${ }^{9}$ This type of public-private cooperation is also described within the context of "the media welfare state", but is discussed under this heading since it also has much to do with market size and certain cooperative traditions (Syvertsen et al., 2014).
} 
rounding stakeholders, such as cultural actors and private media companies (Raats \& Pauwels, 2013, p. 205).

In this part we have taken Norway as a case and discussed four contexts that each illustrates the continuing importance of political and cultural factors for how television is defined and understood. These types of contexts are important for filtering and modifying the general challenges in each national case, and they are crucial for enabling and constraining the means that existing television companies can employ to design strategies for the future.

\section{Strategic Responses of National Broadcasters}

Convergence, as well as the specific challenges related to digital intermediaries, has significant impact on the conditions for existing television companies. Most notably, the future is becoming less predictable for television and it has become more difficult for executives to invest in long-term perspectives (Küng, 2015). Television companies are still expected serve the public sphere as well as competing in the market; in the past as well as in the present this duality has proved a difficult balancing act. We turn now to the third research question: 3) How do traditional television institutions in Norway-public service as well as private-respond to the general and specific challenges and with what impact?

First, a common strategy for both public and private TV companies is to expand onto new platforms to combat audience fragmentation and secure new sources of revenue. Historically, television companies have been afraid of losing out to competitors if they are cut off from new platforms, and have embraced digital television as well as mobile and online services (Enli, 2008; Levy, 1999; McQuail \& Siune, 1998; Moe, 2009). More recently, Norwegian television companies have adapted strategies used by the digital intermediaries, such as releasing drama series for online streaming before aired on broadcast TV, releasing an entire season in one bulk, rather than weekly episodes, launching applications for Apple-TV, iPhone, and Android, and filming in mobile phone friendly format (Jerijervi, 2015). The established broadcasters have also become increasingly aware of the marketing effect of social media, using Facebook, as well as Instagram and Snapchat, as new platforms for distribution of content (Tolonen et al., 2015). The broadcasters typically use digital platforms to create a universe to support the brand and to point users from television programs to mobile and online services, and back to television. In NRK vocabulary, this strategy is termed "keeping them and moving them" (Ihlebæk et al., 2013, p. 478). Moreover, TV companies increasingly facilitate activities on a second screen, and Twitter is particularly used as a "backchannel" for user- debates while watching sports, news events, drama series or entertainment shows (Bruns, Moe, Burgess, \& Burgess, 2015). This has placed tradi- tional broadcasters in a strategically important position, not only as a provider of audio-visual content, but as a point of reference in social media debates and online environments. A study of Twitter hashtags for example found that the established broadcasters and their flagship news programmes are the most used hashtags in Norwegian Twitter debates (Enli \& Simonsen, 2016).

Second, the public and private companies are increasingly keen to cooperate and build alliances in order to protect content and common interests. In particular, there is increased cooperation between the public broadcaster NRK and the private broadcaster TV 2, the second national broadcaster with some public service obligations. As a response to the high costs of sports rights and the small size of the Norwegian TV-market, the two companies joined forces to buy FIFA World Cup (2014), and divided the matches between them. The CEO's of the two companies have also proclaimed their intention to cooperate more strategically in the future, regretting in an interview that they had been too busy competing against each other for rights and distribution to discover that "Netflix was moving straight into their markets grabbing 500,000 customers" (Aune, 2015, authors' translation) Reflecting current technological convergence, TV companies also seek partnership across media sectors, such as when the Norwegian commercial channel TVNorge ${ }^{10}$ recently collaborated with the newspaper $V G$ to acquire the rights to the national football league. Another example which reflects the new potential for cooperation is the partnership between Netflix and the public broadcaster NRK in the production of the series Lilyhammer. Such cross-sector partnership are also challenging, however; the public broadcaster and the US-based technology company turned out to have diverging interests regarding both the storyline and the distribution model (Sundet, 2016). The conflicts reflected a culture crash between a global commercial player and a national player with obligations to produce content reflecting Norwegian culture and identity. In spite of such challenges, both the national and the international co-production has expanded and increased the relevance of the traditional broadcasters in online and mobile environments.

Third, both public and private broadcasters aim for a sustained flow by strategic scheduling, and use national content to reclaim the role as a national cultural arena. In spite of the technical possibility of time-shifting and non-linear viewing, the majority of TV viewing in Norway, and internationally, is still linear. In contrast to the media hype about new intermediaries replacing TV the statistical evidence points towards continuity: "It is an underestimated fact that TV viewing has actually in-

10 TvNorge owned by Discovery since 2012, continues to pull in money. Turnover increased with $10 \%$ in stagnating market in 2014. Apart from main channel TvNorge, all channels (Max, Fem and Discovery) licenced in UK with British rules. 
creased in the last decade" (Tolonen et al., 2015, p. 7). In 2015, linear television accounted for a major share of the average daily viewing time, even among young people, by far exceeding streaming and recorded watching. Moreover, the role of the PBS channels has remained noticeably strong in light of recent market changes; in line with their Scandinavian counterparts, Swedish SVT and Danish DR, the NRK is popular and practically everyone uses public broadcasting or their digital services, most on a daily basis. ${ }^{11}$ Likewise, the main commercial channels in Norway TV 2, TvNorge, and TV3 have largely retained their market positions in spite of increased competition from global players.

This sustainability can be explained by a combination of continuity and change; the broadcasters have not abandoned elementary flow strategies, meaning that they schedule popular lead-in programme early in the evening and seek to build on their popularity throughout the evening. The relationship between a variety of niche channels and the main channels have made the flow more complex, as schedulers lead viewers in vertical and horizontal directions across the company's channels. With the increase in niche channels as well as new digital and mobile platforms, the role of the main channels has become more distinct and might best be described as "the mother ship"; research interviews with producers in Norwegian television show that the web units depend heavily on the TV platform to draw a mass audience and thereby generate interest in the digital and interactive features (Ihlebæk et al., 2013, pp. 475-483). The established broadcasters' main window to the audience is their main channels as this will in turn drive traffic also to their other channels, and to their new digital platforms. The programmes that are most often scheduled in the attractive prime time slots on the main channels are original productions such as high-cost drama series, which provides the public and private TV companies with an advantage in the competition from the global digital intermediaries. In sum, the broadcasters' strategies have impacted on their market shares, and reduced their vulnerability in the new convergent market for audio-visual content.

\section{Conclusion}

The main aim of this article is to discuss the future of television in light of recent changes, and in particular to what degree the impact of convergence and digital intermediaries is a game-changer for traditional television. Taking Norway as an example, we analyse TV as a medium, industry and political and cultural institution in relation to technological and market changes. We

\footnotetext{
${ }^{11}$ Recent audience research shows that more than $90 \%$ of the population tune into the respective public service broadcasting services in Norway (NRK), Denmark (DR), and Sweden (SVT) over the course of a week (see Syvertsen et al., 2014).
}

particularly emphasised the cultural contexts of Norwegian television; the European policy framework, the national arrangement of PSB, the Media Welfare State and characteristics of the Nordic region and the ecosystem approach in which public and private television companies collaborate. Moreover, we analysed the responses from traditional private and public broadcasters to technological changes and market changes related to new global players.

An overarching finding in the analysis is that "the death of television" rhetoric is not supported by empirical evidence, and the rumours about TVs death is thus exaggerated. Even though the TV industry is currently undergoing significant changes, not least as a response to convergence and new digital intermediaries, these changes do not represent the full picture. In tandem with change and renewal, there is stability and continuity. Traditional TV is still an economic, cultural, and social important medium, and as pinpointed by Lotz (2014, p. 170) television remains an incredible profitable industry, yet not as profitable as before.

We have demonstrated that television has also been in transition in previous phases, such as when the monopoly was demolished, when generalist channels were fragmented into niche channels, and when the user-generated audio-visual service YouTube was launched. In light of the importance of television, both as an economic factor in the cultural industry and as a constitutive cultural element, it is fairly logic that television should be in transition. The fact that there are many stakeholders in television, both politically and culturally, and that they will impact on its development in various directions might explain why TV is not stable, but in more or less constant flux. The new turns television has taken during each phase of transition underlines TV's ability to adjust to change, and might even demonstrate the strength, sustainability and success of TV as a medium.

In turn, we found that the development of television is not linear and universal across various cultural contexts; TV is formed not only by technological and economic factors, but also by political, historical, and cultural factors. A reason for the dominance of the "end of television paradigm" is that the US context is often taken as universal, or as argued by Pertierra \& Turner (2013), the "relative disinterest in acknowledging the diverse ways in which television has developed in various parts of the world" (p. 11). Moreover, Pertierra \& Turner (2013, p. 8) explicitly criticise what they call the "mythology of the disappearing state". This article demonstrates that there are diverse approaches to television across different political systems, and that interventions by the state, such as in the Nordic region, impacts on the developments of television to a degree that makes it more useful to talk about several cultural models for television, than to subscribe to one form of technologically-determinist speculation. 


\section{Acknowledgments}

We would like to thank the anonymous reviewers for useful suggestions and comments, and the research network NIPS-Faltin Karlsen, Hallvard Moe, Ole J Mjøs, and Vilde Schanke Sundet-for fruitful feedback in the revision phase.

\section{Conflict of Interests}

The authors declare no conflict of interests.

\section{References}

Aslama, M., \& Syvertsen, T. (2007). Public service broadcasting and new technologies: Marginalisation or remonopolisation. Media Between Culture and Commerce, 4, 167-178.

Aune, O. (2015, May 7). Mens vi slo hverandre i hodet, tok Netflix 500000 norske abonnenter. NRK. Retrieved from http://www.nrk.no/kultur/_-mens-vislo-hverandre-i-hodet_tok-netflix-500-000-norskeabonnenter-1.12349452

Born, G. (2003). Strategy, positioning and projection in digital television: Channel Four and the commercialization of public service broadcasting in the UK. Media, Culture \& Society, 25(6), 774-799.

Bruns, A., Moe, H., Burgess, J., \& Burgess, J. (2015). Twitter hashtags from ad hoc to calculated publics: The power and politics of networked discourse communities. In N. Rambukkana (Ed.), Hashtag Publics. New York: Peter Lang.

Bulck, H. V., \& Donders, K. (2014). Of discourses, stakeholders and advocacy coalitions in media policy: Tracing negotiations towards the new management contract of Flemish public broadcasters VRT. European Journal of Communication, 29(1), 83-99.

Carr, D. (2013, February 24). Giving viewers what they want. The New York Times. http://www.nytimes.com /2013/02/25/business/media/for-house-of-cardsusing-big-data-to-guarantee-its-popularity.html?_r=1

Colapinto, C. (2010). Moving to a multichannel and multiplatform company in the emerging and digital media ecosystem: The case of mediaset group. International Journal on Media Management, 12(2), 59-75.

DAF/COMP/GF13. (2013) Competition issues in television and broadcasting. The OECD Global Forum on Competition. Retrieved from http://www.oecd.org/daf/ competition/TV-and-broadcasting2013.pdf

Dhoest, A. \& Simons, N. (2013). Still TV: On the resilience of an old medium. NECSUS-European Journal of Media Studies, Spring 2013 'Green'.

Donders, K., \& Pauwels, C. (2008). Does EU policy challenge the digital future of public service broadcasting? An analysis of the Commission's state aid approach to digitization and the public service remit of public broadcasting organizations. Convergence: The
International Journal of Research into New Media Technologies, 14(3), 295-311.

Donders, K., Pauwels C., \& Loisen, J. (2013): Editors introduction: Private television in Europe-A new beginning or the beginning of the end? In K. Donders, C. Pauwels, \& J. Loisen (Eds.), Private television in Western Europe. Content, markets, policies (pp. 1120). Basingstoke: Palgrave.

Donders, K. (2013). Fighting a (lost) battle? An analysis of 20 years of private television complaints against the funding of public service broadcasting. In: K. Donders, C. Pauwels, \& J. Loisen (Eds), Private television in Europe: Content, markets and policies (pp.214228). Basingstoke: Palgrave Macmillan.

Doyle, G. (2015). Understanding media economics (2nd ed.). London: Sage.

Dwyer, T. (2010). Media Convergence. Maidenhead and New York: McGraw-Hill/Open University Press.

Ellis, J. (2000). Seeing things. Television in the age of uncertainty. London: I.B. Tauris.

Enli, G. (2008). Redefining public service broadcasting: Multi-platform participation. Convergence. The International Journal of Research into New Media Technologies, 14(1), 105-120.

Enli, G. (2015). Mediated authenticity: How the media constructs reality. New York and London: Peter Lang.

Enli, G., Moe H., Sundet, V. S., \& Syvertsen, T. (2013). From fear of television for television: Five political debates about new media technologies. Media History, 19(20), 213-227.

Enli, G., \& Simonsen, C. A. (2016). 'Social media logic' meets profession norms: Twitter hashtag usage by journalists and politicians. Manuscript submitted for publication.

European Commission. (2015a). Why we need a Digital Single Market. Retrieved from http://ec.europa.eu/ priorities/publications/why-we-need-digital-singlemarket_en

European Commission. (2015b). Contributions and preliminary trends of the public consultation on audiovisual media services (AVMSD). Retrieved from https://ec.europa.eu/digital-agenda/en/news/contri butions-and-preliminary-trends-public-consultationaudiovisual-media-services-avmsd

European Commission. (2016). Television programming of audiovisual European works. Retrieved from http://ec.europa.eu/programmes/creative-europe/ opportunities/audiovisual-support/tv-programming en.htm

Fossbakken, E. (2015, February 15). Netflix-feberen avtar: Etter to år med kraftig vekst, stagnerer strømming av tv-innhold i Norge. Det merker også Netflix. Kampanje. Retrieved from http://kampanje. com/medier/2015/02/netflix-feberen-avtar

Freedman, D. (2008). The politics of media policy. London: Polity Press

Gilder, G. (1992). Life after television. New York: W.W. 
Norton \& Co. Inc.

Girginova, K. (2015). Defining "TV-like" content: The socio-economic and cultural politics of regulating digital content in the UK. Paper presented at the annual conference of the International Communication Association, 21-25 May, San Juan, Puerto Rico.

Gripsrud, J. (Ed.). (2010). Relocation television: Television in the digital context. New York: Routledge.

Harris, S. (2015, November 9). Cord-nevers could be bigger threat to TV than cord-cutters. CBC News. Retrieved from http://www.cbc.ca/news/business/ cord-nevers-cord-cutters-tv-1.3308072

Hastings, R. (2015, February 27). Slik tar Netflix kontroll over verdens TV-skjermer. A-magasinet. Retrieved from http://www.aftenposten.no/amagasinet/Sliktar-Netflix-kontroll-over-verdens-TV-skjermer7914690.html

Hiler, J. (2002). Blogosphere: The emerging media ecosystem. Microcontent News, 28.

Hill, A. \& Steemers, J. (2011). Big formats, small nations. Does size matter? In G. F. Lowe \& C.S. Nissen (Eds), Small among giants: Television broadcasting in smaller countries (pp. 203-217). Göteborg: Nordicom.

Ibarra , K. A., Nowak, E., \& Kuhn, R. (2015). Public service media in Europe: A comparative approach. London and New York: Routledge.

Ihlebæk, K., Syvertsen, T., \& Ytreberg, E. (2013). Keeping them and moving them: TV scheduling in the phase of channel and platform proliferation. Television and New Media, 15(5), 470-486.

Jenkins, H. (2006). Convergence culture. Where old and new media collide. New York and London: New York University Press.

Jensen, K. B. (2010). Media convergence: The three degrees of network, mass, and interpersonal communication. London \& New York: Routledge.

Jerijervi, D. R. (2015, December 22). NRK går "mobile first" med ny dokumentar: Tester ut video i høydeformat. Kampanje. Retrieved from http://kampanje. com/tech/2015/12/nrk-tester-ut-video-i-hoydeformat

Johnston, C. (2012, December 28). The Netflix lobby in Washington spent \$1 million in two years: Making social media integration for Netflix legal is a costly endeavor. Arstechnica. Retrieved from http://arstec hnica.com/tech-policy/2012/12/the-netflix-lobby-inwashington-spent-1-million-in-two-years/

Katz, E., \& Scannell, P. (2009). The end of television? Its impact on the world (so far). The Annals of the American Academy of Political and Social Science, 625(1).

Kenyon, A. T. (2014). Free-media-speech: Free speech and public media. International Journal of Media \& Cultural Politics, 10(2), 155-162.

Küng, L. (2015). Innovators in digital news. London: IB Tauris.

Lasica, J. D. (2003). Blogs and journalism need each other. Nieman Reports, 57(3), 70-74.
Levy, D. (1999). Europe's digital revolution: Broadcasting regulation, the $E U$ and the nation state. London and New York: Routledge.

Lotz, A. D. (2007). If it's not TV, what is it? The case of US subscription television. In S. Banet-Weiser, C. Chris, \& A. Freitas (Eds.), Cable visions: Television beyond broadcasting (pp. 85-102). New York: New York University Press.

Lotz, A. D. (Ed.). (2014). The Television will be revolutionized. New York and London: New York University Press.

Lowe, G., \& Martin, F. (Eds.). (2014). The value of public service media: RIPE@2013. Göteborg: Nordicom.

MarketingCharts. (2014, August 5). Social media's impact on TV on the rise. MarketingCharts. Retrieved from http://www.marketingcharts.com/online/social -medias-impact-on-tv-on-the-rise-44598/

Mansell, R. (2015). The public's interest in intermediaries, Info, 17(6), 8-18.

McKinsey \& Company. (2004, September). Review of public service broadcasting around the world. Retrieved from http://stakeholders.ofcom.org.uk/ binaries/consultations/psb2/annexes/wp3mck.pdf

McQuail, D., \& Siune, K. (Eds.). (1998). Media policy: Convergence, concentration and commerce. London: Sage.

Kulturdepartementet. (2015, June 19). Open og opplyst. Allmennkringkasting og mediemangfald. Stortingsmelding 38 2014-2015. Retrieved from https://www.regjeringen.no/globalassets/upload/ku d/kulturvernavdelingen/maalbruk/hoeringsnotat_nr k_plakaten.pdf

Mendel, T. (2000, April 10). Public service broadcasting. A comparative legal survey. Asia Pacific Institute for Broadcasting Development. UNESCO: Kuala Lumpur. Retrieved from: http://www.unesco.org/webworld/ publications/mendel/jaya_index.html

Miller, T. (Ed.). (2003). Television: Critical concepts in media and cultural studies. London: Routledge.

Moe, H. (2007). Commercial services, enclosure and legitimacy: Comparing contexts and strategies for PSM funding and development. In G. F. Lowe \& J. Bardoel (Eds.), From public service broadcasting to public service media. RIPE@2007 (pp. 51-69). Göteborg: Nordicom.

Moe, H. (2009). Public broadcasting, the internet and democracy. Comparing policy and exploring public service media online (Doctoral dissertation). University of Bergen, Norway.

Moe, H., \& Syvertsen, T. (2009). Researching public service broadcasting: Policy, institutions, democracy and post-modern approaches. In K. Wahl-Jorgensen \& T. Hanitzsch (Eds.), Handbook of journalism studies (pp. 398-412). New York: Lawrence Erlbaum.

Morrison, K. (2014, June 27). Online streaming services are becoming a threat to broadcast television. Social Times. Retrieved from http://www.adweek.com/ 
socialtimes/online-streaming-vs-broadcast-television $/ 200388$

Myhre, N. K. (2015) "NRKs omdømme styrket". Retrived from http://www.nrk.no/informasjon/nrks-omdom me-styrket-1.12242631

Napoli, P. (2014). Digital intermediaries and the public interest. LSE. Retrieved from http://blogs.lse.ac.uk/ mediapolicyproject/2014/11/07/digital-intermediari es-and-the-public-interest-standard-in-algorithm-gov ernance

Naughton, J. (2012, January 15). Traditional TV has survived the net threat, but for how much longer? The Guardian. Retrieved from http://www.theguardian. com/commentisfree/2012/jan/15/john-naughton-tvversus-youtube

Ofcom. (2013). Appeal by BBC worldwide limited against a notice of determination by ATVOD that the provider of the service "Top Gear YouTube" (www.you tube.com/topgear) has contravened sections 368ba and 368d(3) (za) of the Communications Act 2003. Retrieved from http://stakeholders.ofcom.org.uk/ binaries/enforcement/vod-services/top-gear-youtu be-decision.pdf

Olsson, J., \& Spiegel, L. (Eds.). (2004). Television after TV: Essays on a medium in transition. Durham: Duke University Press.

Pertierra, A. C., \& Turner, G. (2013). Locating television: Zones of consumption. London and New York: Routledge.

Raats, T., \& Pauwels, C. (2013). "Best frenemies forever?" Public and private broadcasting partnership in Flanders. In K. Donders, C. Pauwels, \& J. Loisen (Eds.), Private television in Western Europe (pp. 199-213). Basingstoke: Palgrave.

Riemer, K., Gal, U., Hamann, J., Gilchriest, B., \& Teixeira, M. (2015). Digital disruptive intermediaries.: Sydney: Capgemini. Retrieved from https://www.au.capgemi ni.com/resource-file-access/resource/pdf/disruptive _intermediaries_final.pdf

Staiger, J., \& Hake, S. (Eds.). (2009). Convergence media history. New York and London: Routledge.

Strangelove, M. (2015). Post-TV: Piracy, cord-cutting, and the future of television. Toronto and London: University of Toronto Press.

Sundet, V. S. (2016). Still "Desperately seeking the audience"? Audience making in the age of media conver- gence (the Lilyhammer experience). Northern Lights, 14(1), 11-27.

Syvertsen, T. (1992). Public television in transition: $A$ historical and comparative analysis of the $B B C$ and the NRK (Doctoral dissertation). University of Leicester, Leicester.

Syvertsen, T. (1997). Paradise lost: The privatization of Scandinavian broadcasting. Journal of Communication, 47(1), 120-127.

Syvertsen, T. (2008). Allmennkringkasting i krise-Not! Norsk medietidsskrift, 15(3), 211-235.

Syvertsen, T., Enli, E., Moe, H., \& Mjøs, O. J. (2014). The media welfare state: Nordic media in the digital era. Ann Arbor: The University of Michigan Press.

Sønneland, H. (n.d.). The Norwegian Constitution's article 100. Norway: Norwegian Ministry of Culture and Church Affairs.

Tobiassen, M. (2015, February 11). Netflix dropper Widvey-møte: I dag begynner dragkampen om hvem som skal finansiere norsk film- og tv-produksjonuten Netflix. DN. Retrieved from http://www. dn.no/etterBors/2015/02/11/2200/Medier/netflixdropper-widveymte

Tolonen, K., Sørensen, H., Meum, M., Prebensen, I., Blystad, E., Braathen, L., \& Eide, T. (2015). Oppsummeringen 2014. NRK analyse.

Turner, G., \& Tay, J. (Eds.). (2009). Television studies after TV: Understanding television in the postbroadcast era. London and New York: Routledge.

Vaidhynathan, S. (2011). The googlization of everything (and why we should worry). Los Angeles: The University of California Press.

Vollan, M. B. (2015, June 1). Vil at Netflix skal betale: Kulturminister Thorhild Widvey $(\mathrm{H})$ mener at Netflix og andre strømmetjenester må bidra til å finansiere norske filmer og tv-serier. Klassekampen. Retrieved from http://www.klassekampen.no/article/2015060 1/ARTICLE/150609996

Weissmann, E. (2009). Paying for fewer imports: The BBC license fee 1975-1981 and attitudes toward American imports. Television \& New Media, 10(6), 482-500.

Williams, R. (2008). Television: Technology and cultural form. London and New York: Routledge. (Original work publish 1974)

\section{About the Authors}

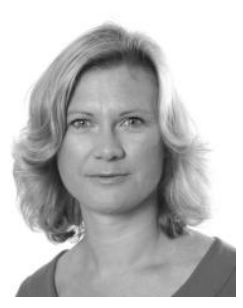

\section{Dr. Gunn Enli}

Gunn Enli is Professor of media studies at the University of Oslo. Her research interests include media policy, political communication, social media and media history. She has published several books in Norwegian and English and articles in international journals. Her latest book is Mediated Authenticity: How the Media Constructs Reality (Peter Lang, 2015). She is currently the project leader of the international research project "Social Media and Election Campaigns", and a partner in the comparative project "Media companies and the Public Interest". 


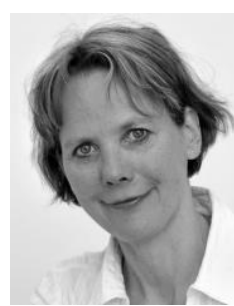

\section{Dr. Trine Syvertsen}

Trine Syvertsen is Professor of media studies at the University of Oslo. Her research interests include media history, television studies, public broadcasting and media policy. She has published several books and articles in Nordic and international journals. Her latest book is The Media Welfare State: Nordic Television in the Digital Era (Syvertsen, Enli, Mjøs, \& Moe, University of Michigan Press, 2014). She is currently working on a book on Media Resistance: Protesting, Disliking and Abstaining from Media and taking part in a collaborative research project on "Media Companies and the Public Interest". 